\title{
RELATIONSHIP AMOUNG BODY MASS INDEX, HISTORY OF MATERNAL MENARCHE AND EXPOSURE OF PORNOGRAPHIC MEDIA WITH MENARCHE AGE IN ELEMENTARY SCHOOL STUDENTS, JAMBI
}

\author{
Dina Seprina, Adelina Fitri, M. Dody Izhar \\ Universitas Jambi, Indonesia
}

\begin{abstract}
Background: Menstruation is the cyclic, orderly sloughing of the uterine lining, in response to the interactions of hormones produced by the hypothalamus, pituitary, and ovaries. Many factors influence the age of menarche, such as body mass index, history of maternal menarche and exposure to pornographic media. This study aimed to determine the relationship between body mass index, history of maternal and exposure to pornographic media with menarche age in elementary school students in Jambi City.

Subject and Methods: This was a cross sectional study conducted at elementary school 207/ IV Jambi City, Indonesia. A sample of 74 students was purposively sampled. The dependent variable was age of menarche. The independent variables were body mass index (BMI), history of maternal menarche, and exposure to pornographic media. The data were collected by questionnaires, digital scales, and microtoise. Bivariate analysis was performed by Chi-Square.

Results: Large body mass index $(\mathrm{PR}=4.50 ; 95 \% \mathrm{CI}=0.40$ to 51.29$)$, history of early menarche $(\mathrm{PR}=9.75 ; 95 \% \mathrm{CI}=3.35$ to 28.36$)$, and exposure to pornographic media $(\mathrm{PR}=4.81 ; 95 \% \mathrm{CI}=$ 1.74 to 13.29 ), accelerated age of menarche.

Conclusion: Large body mass index, history of early menarche, and exposure to pornographic media, accelerate age of menarche.
\end{abstract}

Keywords: Menarche, BMI, Pornography Media

Correspondence:

Adelina Fitri. Universitas Jambi. Jl. Lintas Jambi - Muara Bulian No. Km. 15, Mendalo Darat, Muaro Jambi Regency, Jambi, Indonesia. Email: adelinafitri@unja.ac.id. o81272030308. 